\title{
UNA MIRADA SOBRE ALGUNAS TENDENCIAS Y PRÁCTICAS RELIGIOSAS EN NUESTRO CONTEXTO ${ }^{1}$
}

\author{
Ernesto Fajardo Pascagaza ${ }^{2}$ \\ José de Jesús Prada ${ }^{3}$
}

\begin{abstract}
Resumen: Este artículo recoge y comparte una visión particular y panorámica sobre algunas características y tendencias de varias prácticas religiosas presentes en el contexto de Bogotá y sus posibles consecuencias en los procesos reconfiguración religiosa de nuestra ciudad. En esencia este texto tiene dos partes: en la primera se busca caracterizar la religiosidad popular más como fruto del contacto entre diversos grupos religiosos que como manifestaciones sincretistas, mágicas, paganas... o de la nueva era. En la segunda parte se intenta focalizar la mirada sobre algunos procesos de reconstrucción de la expresión religiosa, procesos que se gestan en las realidades de los pueblos y sus contextos práxicos y vivenciales.
\end{abstract}

Palabras clave: Prácticas religiosas, secularización, reconfiguración religiosa.

1 CHARACTERIZATION AND TRENDS IN RELIGIOUS PRACTICES AND THEIR IMPACT ON SECULARIZATION RELIGIOUS IN LATIN AMERICA AND RECONFIGURATION. Artículo producto de la investigación realizada al interior del Grupo de Investigación ALETHEIA de la Universidad Santo Tomás, en torno a la relación entre educación, ética y política.

2 Magister en Filosofía y Magister en Educación de la Universidad Santo Tomás, Magister en Teología, Licenciado en Teología y Licenciado en Filosofía, Especialista en Filosofía y Educación, con Formación Sacerdotal, se desempeña como docente del Departamento de Humanidades y Formación Integral de la misma institución. Dirección postal: Carrera 9 51-11, Bogotá, Colombia. Integrante del Grupo de Investigación ALETHEIA. Miembro del Observatorio de la Diversidad Religiosa y Cultural en América Latina y el Caribe (ODREC). Correo electrónico: ernestofajardo@usantotomas.edu.co.

3 Doctor en Teología, Pontificia Universidad Javeriana (Bogotá). Magister en Teología Bíblica, Pontificia Universidad Bolivariana (Medellín). Licenciado en Teología, Pontificia Universidad Bolivariana (Medellín) Anteriormente, en ese mismo claustro universitario recibió los títulos de STD, STL y STB en Teología. Licenciado en Filosofía, Universidad Santo Tomás (Bogotá). Contador Público por la Universidad Cooperativa de Colombia (Bucaramanga). Ha sido profesor de la Pontificia Universidad Javeriana y se desempeñó durante cinco años como Director Académico del Instituto Internacional de Teología a Distancia, asociado a dicha Universidad. Ha sido profesor en las Universidades Javeriana, Bolivariana, Juan de Castellanos y actualmente de la Universidad Santo Tomás. Forma parte del grupo de investigación Aletheia y del Observatorio de la Diversidad Religiosa y Cultural en América Latina y el Caribe (ODREC). Correo electrónico: josedejpradav@gmail.com. 


\title{
A LOOK AT SOME RELIGIOUS TRENDS AND PRACTICES IN OUR CONTEXT
}

\begin{abstract}
This article intends to present the features and tendencies of religious practices and their influence on secularization and religious reconfiguration in Latin America. Esentially, this text contains two parts: the first seeks to characterize how the religious diversity is expressed based on its ethnical and social reality in each culture where secularization has generated: mixed manifestations, magical and mythical expressions, religious reconfigurations from the New Age. A second part emphasizes on characterizing the reconstruction processes of religious expression, processes that are developed in people's day-to-day contexts.
\end{abstract}

Keywords: Religious practices, secularization, religious reconfiguration

\section{Introducción}

En la historia de la humanidad se conservan religiones y expresiones religiosas que en su devenir han sido permeadas por creencias y prácticas paganas consideradas como expresiones de la religiosidad popular que poco a poco se arraigan, esto se evidencia en la vida cotidiana del hombre ${ }^{4}$.

Se encuentran diversidad de iglesias y comunidades producto de los múltiples procesos de mezclas culturales y construcción de identidades religiosas y sociales al interior de las comunidades. Ahora bien, se evidencian religiones que se han ponderado y se evidencian más que otras en la realidad de los pueblos, ello depende de los contextos sociales y culturales y la asimilación de las tradiciones de generación en generación. En este sentido también surgen sincretismos y modificaciones desde la religiosidad popular frente a lo predominante y supraestructural, lo que llega a convertirse en factores disociantes de la ortodoxia religiosa vista de forma superficial por algunos sectores sociales.

A partir del proceso de la secularización se manifiestan diversos cambios en la praxis religiosa y entre los más sobresalientes están los que a continuación se argumentan. En primer lugar, se encuentra un marcado pero lento declinar de la religiosidad desde sus manifestaciones externas, culturales, públicas y por consiguiente la actividad institucional presencial de las iglesias. Aun cuando hay denominaciones religiosas con profundo activismo desde lo cultual, desde lo ritualizante, también hay apatía e indiferencia por la participación en el culto institucionalizado.

Un segundo aspecto que suscita reflexión es la progresiva independencia de la cultura, las prácticas políticas y la sociedad con respecto a la visión que tiene la religión sobre el hombre y la sociedad.

Un tercer aspecto, y no menos importante, es la desacralización de la naturaleza y en este sentido, el papel que desempeña el hombre sobre ella a partir

4 Delgado, La religiosidad popular: en torno a un falso problema, 20. 
de su injerencia en la construcción de escenarios de ciencia y tecnología que por lo general lleva a su destrucción. Con el transcurrir del tiempo el hombre se ha visto abocado a plantear nuevos paradigmas relacionantes a partir de su contacto con los demás, consigo mismo, con la naturaleza y con la concepción que tengan de Dios. Esto ha dado pie a una modernización caracterizada por una creciente ateización y atomización de la expresión religiosa que poco a poco ha ido perdiendo significatividad, especialmente para las nuevas generaciones. A estos fenómenos se suma la agudización de los problemas económicos, políticos, sociales, culturales y espirituales presentes en todas las esferas de las identidades sociales e individuales permeadas por las megatendencias de la avante globalización que rezaga y afecta todo lo que tiene que ver con las expresiones de lo religioso.

\section{Caracterización de las expresiones de la diversidad religiosa.}

El hombre asume sus relaciones sociales con sentido de pertenencia su vinculación a escenarios religiosos institucionales, pero da lugar al mismo tiempo a manifestaciones de religiosidad que aunque surgen con cierta timidez y recato, poco a poco se imponen en el espectro social. Este comportamiento ha dado lugar a expresiones y concepciones que son asumidas por personas que tienen como referente una religión institucional y asumen prácticas que las vuelven compatibles con su credo original. Por lo tanto, estos comportamientos hacen que las personas den lugar a un vívido sincretismo transcultural que llega, convence y se impone con una fuerza poderosa que trasciende a quienes se dejan involucrar existencialmente con estas prácticas de origen aborigen y afroamericano. Estas prácticas han trascendido históricamente la cotidianidad cultural de los pueblos de tal manera que superviven de generación en generación en ritos y devociones ancestrales 5 . De alguna forma son sistemas que se han conservado y que han logrado manifestarse en rituales y ceremonias de devoción.

Las regiones y los pueblos se permean de la experiencia religiosa brindándole sentido y razón de existir a su vida diaria. Aun cuando llegan nuevas manifestaciones sociales y religiosas las culturas conservan y mantienen vestigios de su identidad religiosa modificada y condicionada por los sincretismos históricos de influencias externas. La autoidentificación étnica que en muchas ocasiones es de carácter social tiende a ser factor inequívoco de identidad cultural, social, política y religiosa.

Los pueblos han manifestado su religiosidad a partir de cultos externos convirtiéndose en comportamientos sociales que han trascendido la historia de generación en generación mediante devociones y rituales a imágenes milagrosas. La religiosidad es la forma como se concretiza la religión en el ser humano en su unión y búsqueda de Dios y por consiguiente la búsqueda de respuestas a sus situaciones límite. La religiosidad es la manera como el pueblo vivencia su religión y su necesidad de relacionarse con Dios. Ahora bien, esta manifiesta relación con la

5 Houtart, Sociología de la religión, 26.

Signos, Lajeado, ano 39, n. 1, p. 316-331, 2018. ISSN 1983-0378 
divinidad se da con la intermediación de los santos, la Virgen María y los ángeles en sus diversas advocaciones. Esta relación se da en el seno de la Iglesia expresada en creencias concretas y ritualizadas en ejercicios de piedad que se hacen evidentes en sentimientos devocionales respecto a determinadas imágenes sagradas que se han contextualizado dependiendo de los escenarios geográficos, culturales, económicos y políticos. Es preciso anotar que hay multiplicidad de valores involucrados en la experiencia religiosa dado que muchos ejercicios piadosos dependen de un santuario o romerías tradiciones ancestrales. Incluso varios de estos lugares se convierten en escenarios de poderío económico y mercantilista al vender una advocación determinada y el reconocimiento de un culto posicionado a los fieles que la veneran. Este fenómeno se ha logrado porque el lugar ha adquirido relevancia a partir de milagros, favores concedidos, prodigios y señales divinas.

Es evidente que la participación sacramental ha disminuido pero al mismo tiempo se evidencia un crecimiento participativo creciente en procesiones y demás celebraciones masivas y públicas las cuales tienen como notas características la masificación, la pasividad y el estar como simples espectadores de un evento social que convoca a los fieles a dejarse tocar por la presencia divina plena de poder y milagrosa.

Ante el milagro, el fiel asume la actitud de respeto, reconocimiento y agradecimiento porque ha obtenido los favores de Dios a través de la intercesión de algún santo. La fuerza del milagro por sí mismo se impone así como también se hace evidente a partir del testimonio de quienes dan fe del mismo y lo difunden por doquiera que se hallen. El milagro, desde la piedad popular, tiene un acento emotivo, sentimental el cual responde de manera práctica a un favor solicitado y que ha sido satisfecho. En este sentido, un santo es realmente un santo porque en esencia es santo. Por otra parte, para la expresión religiosa oficial, el milagro es celosamente estudiado y racionalizado teológicamente y corresponde a la naturaleza de santidad y virtuosidad de quien lo hace y se puede testimoniar históricamente.

Las fiestas son parte fundamental de las expresiones de la religiosidad popular porque permiten mostrar externamente los sentimientos religiosos. En las fiestas se celebran advocaciones de santos quienes han concedido favores a muchos feligreses y esto ha dado lugar a que estas festividades sean famosas y convoquen multitudes en reconocimiento a la imagen y por consiguiente al santo de su devoción. Estos lugares de peregrinación y romerías se convierten en centros religiosos que comercializan objetos de diversa índole como láminas, vitelas, imágenes, entre otros para que los visitantes los adquieran y se unan en ferviente oración agradeciendo las bondades de quien le recuperó de alguna enfermedad que padecía o una situación compleja laboral o familiar. En muchos lugares que la imagen sagrada ha sacralizado se ofertan novenas, velones, lápidas para inscribir mensajes así como estipendios de acción de gracias para nombrar en las celebraciones eucarísticas. En el lenguaje de la piedad popular, una celebración con cantos y música de acompañamiento se tiene como de más valía ante el santo a quien se le pide su intercesión. El hombre siempre ha estado en actitud de búsqueda de Dios para pedirle ayuda y también para agradecerle por los bienes recibidos. 
La epifanía del amor de Dios se hace presencia cuando también los hombres lo buscan desde una expresión religiosa; el hombre agradece y se identifica con un santo o una advocación de la Virgen para rendir tributo, honor y adoración. Por eso se visitan santuarios como camino hacia lo sagrado para implorar misericordia, sanación y bendición a partir de una imagen mediadora. La religiosidad popular ha ayudado a consolidar las comunidades, a generar cohesión, sentido de pertenencia, identidad y vinculación a partir de una devoción particular en un territorio determinado con significado de tradición que se testimonia de generación en generación.

La religiosidad popular es un escenario con excelentes y ricas posibilidades para expresar el imaginario colectivo de los pueblos los cuales asumen formas de vida y experiencias cotidianas que comparten a partir de la asunción de sus problemas y la manera como los enfrentan. En este sentido, esta expresión religiosa es una forma de conciencia social en la que intervienen representaciones de orden interpersonal y comunitario así como relaciones con la naturaleza y lo sobrenatural. De esta manera se valida el culto como la forma en que el hombre busca relacionarse con su objeto religioso de devoción dándole sentido a su existencia necesitada y que busca se favorecida y escuchada en sus peticiones, ruegos, rituales y ofrendas cultuales.

Esta religiosidad se expresa como un movimiento que se distancia de la ortodoxia oficial al adoptar comportamientos espontáneos incluyendo elementos de religiones autóctonas indígenas y africanas. Asume variables religiosas de otras creencias que pragmatiza y contextualiza según las regiones y los pueblos donde se manifieste.

En la religiosidad popular subyace una oportunidad altamente evangelizadora y parte del trabajo de la Iglesia institucional es exhortarla y animarla para que como lugar teológico, las personas logren un proceso de conversión conforme a la verdad del Evangelio. Los pueblos viven un patrimonio vivo de fe que se expresa en las celebraciones en las que participa y le da sentido a su existencia. El anuncio de la Buena Nueva, del mensaje de salvación es asumido con buena actitud receptiva por parte de las personas que asumen en su cotidianidad estas prácticas de religiosidad popular y esto debe ser visto como una generosa oportunidad para establecer relaciones de común unidad de acompañamiento y servicio entre lo popular y la oficial. La religiosidad popular tiene una riqueza inmensurable e inherente a su propia esencia la cual ha permeado las expresiones culturales de los pueblos y se ha posicionado en escenarios de manera vital y auténtica.

La esfera de lo público es inherente a la expresión religiosa porque es allí donde el creyente vivencia su fe en ritos y ceremonias tradicionales, es allí donde expresa socialmente su sentido de pertenencia a una u otra denominación religiosa; lo paradójico es que cada vez más estas manifestaciones públicas han sido desplazadas por una apropiación de las prácticas privadas de carácter individual que se alejan del sentido comunitario que es esencial a la vivencia de la experiencia religiosa. De alguna forma las personas siguen creyendo a su manera, se acomodan a 
prácticas menos comunitarias e institucionalizadas para dar lugar a expresiones más privadas, más personalizadas y en este horizonte de posibilidades surgen tendencias que tocan a los individuos, en particular quienes desde su mismidad aceptan manifestaciones desde lo mágico y sobrenatural integrándolo a su religiosidad y que al creer que está fortaleciendo su experiencia religiosa lo que hace es debilitarla en las tradicionalidades mágicas que combina en su vivencia religiosa.

De por sí, las prácticas religiosas hacen revitalizar las relaciones sociales entre los individuos (los practicantes) y dan sentido a las identidades grupales y las fortalecen para abatir las adversidades del mundo actual. En este sentido, desde la experiencia de fe y la creencia en Dios, la religiosidad se estructura en lo fundamental, en la vivencia comunitaria, en la expresión solidaria de la comunidad que se reúne para celebrar su fe como asamblea.

Todo esto conlleva a que las instituciones religiosas ingresen a procesos de reingeniería adaptándose a los nuevos modelos sociales matizados por nuevas expresiones religiosas pragmáticamente visibles en la proliferación de sinnúmero de agrupaciones religiosas institucionalizadas o no. Surgen por lo tanto múltiples asociaciones de brujos, de lectores del tarot, de curanderos, de rezanderos, de magos y chamanes así como paralelamente de eventos académicos que se dedican a poner en tela de juicio, a dogmatizar, problematizar y analizar propuestas culturales. Igualmente surgen propuestas comercializantes a partir de literaturas religiosas, de realidades religiosas cosificadas y medios y mediaciones cultuales en el contexto de lo religioso.

Por otra parte, es claro que la presencia de nuevos movimientos religiosos ha incidido en las religiones institucionalizadas, ya que estas han tenido que comprender nuevas realidades desde la tolerancia y el advenimiento de expresiones participativas que se imponen en el horizonte de las personas, ideas y actividades heterodoxas, de las comunidades y las individualidades muchas de ellas matizadas por la influencias de movimientos místicos de carácter oriental.

Surge entonces el valor de la meditación, del autocontrol, de la ascesis mística, del contacto con experiencias ancestrales, de experiencias médicas y sanativas a partir de terapias alternativas así como de movimientos científicos y gnósticos, de cienciología, de terapias zodiacales que de una u otra forma han influido en el devenir histórico de los pueblos y su idiosincrasia. Es evidente que hay individuos y comunidades que se dejan tocar por estas nuevas propuestas de modo más sensible y caen en el sincretismo de lo absurdo pero muy significativas para ellos.

Surgen megatendencias en este espectro de la nueva era y cada vez son más quienes optan por estas, como es el caso de la ufología, de la teosofía, entre otras. Paralelamente van apareciendo iglesias institucionalizadas y otras de incipiente naturaleza de carácter protestante de las cuales algunas, se ubican en bodegas inmensas así como otras en espacios reducidos de garaje y ofrecen sus propuestas 
religiosas para captar feligreses o adeptos que en muchas ocasiones rayan con el fanatismo y el proselitismo fundamentalista ${ }^{6}$.

La nueva era como movimiento ha despertado interés en su apreciación tanto que el número de adeptos es cada vez mayor y considera que es una nueva forma de vivenciar la religión, porque de alguna manera responde al vacío existencial interior que hay en las personas. Este acercamiento busca superar el vacío frente al poder de las tecnologías y dirigen su interés hacia la búsqueda de lo sagrado, de lo místico y lo espiritual desligado de las ataduras de las tradicionales expresiones religiosas. Esta propuesta religiosa es una expresión sincrética que asume elementos de religiones orientales, de las tendencias esotéricas, del gnosticismo, del espiritismo, de la mitología griega, de las tendencias ecológicas, de la astronomía, de la astrología, del yoga así como de las religiones ancestrales. En este sentido, la nueva era ha sido tomada como una religión nueva de carácter universal que atrae a religiosos, indiferentes y ateos porque permite acceder a un dios panteísta, quien es una gran conciencia cósmica, plena de energía y que se manifiesta en la cosmovisión dialéctica entre lo consciente y lo inconsciente, entre el bien y el mal, entre la energía positiva y la energía negativa.

Las prácticas religiosas existen siempre en forma inculturada, con un fuerte arraigo en la tradición de los pueblos y con una gran carga simbólica, cuando están vigentes. Nuestra realidad religiosa es mestiza y sus raíces arrancan de la religiosidad nativa, de la africana y de la hispana que se encontraron, mezclaron y chocaron, dando como resultado el hoy de la religiosidad popular.

En 1998, en la ciudad de Puebla, en la asamblea de los obispos latinoamericanos, se acuñó con relevante importancia el término religiosidad popular?

Esta manifestación cultural y religiosa adoptada por los pueblos latinos lleva en su esencia la sabiduría de los mismos, la forma cómo aprehenden su entorno y lo ritualizan, cómo responden a las grandes preguntas existenciales matizadas del espíritu cristiano preferiblemente celebrado por los pobres. La religiosidad tiene como referente el hecho religioso y su práctica. En la religiosidad se vivencian creencias, prácticas así como principios normativizantes de una religión. En este sentido, lo popular atañe al carácter cultural de lo religioso y este matizado por lo folklórico que vivencia el pueblo ${ }^{8}$.

Surge una aproximación práxica-dialéctica entre la religión oficial y la religiosidad popular al surgir ésta de la religión, pero se configura con características sui generis. Son manifestaciones más sencillas y de acercamiento abierto y cercano con la divinidad, que abandona el esquematismo de los paradigmas retóricos clericales cerrados e intelectuales, de ortodoxias y dogmatismos doctrinales por una forma de

6 Gil y Nistal, New age, 28.

7 CELAM, Puebla: La Evangelización en el presente y futuro de América Latina, 444, 447 y 448.

8 Maldonado, Introducción a la religiosidad popular, 14. 
vida religiosa más emocional, más espontánea, más festiva y más popular. En este sentido, la religiosidad popular es la manifestación del sentimiento religioso y la esencia de la sabiduría popular que se expresa como forma de vida cultual arraigado y con sentido de pertenencia e identidad desde la cotidianidad de su existencia. La ortodoxia religiosa de la religión oficial riñe sociológicamente con el fenómeno característico de la religiosidad popular'. Lo sagrado y lo profano constituyen dos ámbitos de la vida humana distintos, pero no incomunicados.

En la religión oficial se celebran los sacramentos y en el mismo escenario se están realizando ritos sobre la vida y la muerte. Es el caso del sacramento del bautismo y la celebración de exequias que se celebran al interior de un templo; se bendicen los niños, se bendicen las imágenes y también se bendice el ataúd y se hace una procesión al cementerio cantando y repitiendo letanías y rosarios antes de enterrar al difunto. Es decir, que tanto lo popular como lo oficial se complementan en la expresión sencilla de fe de los pueblos.

Un factor que está presente en la piedad popular es el sincretismo como resultado de las múltiples realidades culturales en el proceso de apropiación y transculturación de los pueblos. Desde la religiosidad popular se construye una visión religiosa del mundo que para ${ }^{10}$ responde a los intereses de emancipación del pueblo así como para Paul Richard es una expresión que se opone a la visión dominante de la religión oficial ${ }^{11}$.

La expresión cristiana católica y protestante ha estado presente siempre en el devenir histórico de los latinoamericanos aunado a un subproducto cultural de mezclas y combinaciones propias de la religiosidad popular, lo cual genera identidad étnica que trasciende lo doctrinal y dogmático, lo institucional y cultual, así como las categorizaciones sociológicas, antropológicas y teológicas que intentan interpretar este fenómeno heterogéneo latinoamericano. Los pueblos construyen sus imaginarios colectivos a partir de una cosmovisión popular sencilla, pero significativa de su relación con lo trascendente y divino lo cual es obtenido a partir de la mediación de imágenes, de peregrinaciones, de eventos mágicos, de santos, de la virgen y de los muertos y esta realidad en cierta forma los margina de la ortodoxia institucional de la religión.

La praxis de los pueblos se evidencia en su cotidianidad de pobreza y marginalidad, de injusticia social y dependencia a los sistemas opresores y en este orden de ideas se genera una nueva forma de hacer teología ${ }^{12}$, de involucrar la religión

9 Eliade, Aspectos del mito, 36.

10 Boff, Igreja, carisma e poder. 183.

11 Richard, Religión y política en América Latina, 49.

12 Gutiérrez, Teología de la liberación, 40. 
en la realidad existencial de los pueblos oprimidos buscando emanciparlos ${ }^{13}$. No resta decir que la religiosidad popular ha sido reconocida como canal de valores del pueblo, en esto se manifiesta el ethos cultural y ligado a procesos revolucionarios y de cambio social que da lugar, de manera indirecta, a posibles manipulaciones económicas, políticas, religiosas, ideológicas y de militancia instrumentalizada de esta irrupción de los pobres en la Iglesia. La religiosidad popular, en América Latina, se convierte en motor impulsador a la lucha por el cambio de las estructuras de injusticia que padecen los pueblos oprimidos y subyugados por el poder alienante de quienes no han hecho la opción preferencial por los pobres y necesitados. Es una religiosidad del pueblo, es decir, del pobre, del oprimido.

La religiosidad popular es una manifestación de miedo frente a Dios y se evoca su presencia preferiblemente en los momentos nefastos ${ }^{14}$. El universo es incompresible para el hombre y lo hierofánico está en la manifestación sagrada de Dios expresado en la cotidianidad de la existencia humana quien busca auxilio y cuidado de parte de Dios así sea en la superstición. Una figura que trasciende estas expresiones es el Cristo sufriente y no el resucitado precisamente porque el pueblo vivencia más el misterio de la muerte y el sufrimiento.

En las expresiones de la religiosidad popular se mezclan paralelamente lo sagrado con la superstición y la magia. En consecuencia, se le concede valor de milagroso a lo mágico y mágico a lo milagroso. Un lugar sagrado es respetado incluso desde lo mágico y lo supersticioso. Ahora bien, esto no significa que todo sea asumido de esta manera, porque también está presente la apertura hacia lo trascendental, hacia lo sagrado lo cual hace despertar una conciencia de respeto a lo mistérico, a lo religioso como un valor supremo que une al hombre con Dios. La religiosidad popular ha evolucionado en su aceptación desde un primer momento como fe imperfecta, luego como fe legítima y en la actualidad como una expresión auténtica de $\mathrm{fe}^{15}$.

Indiscutiblemente, para la Iglesia, la religiosidad popular es una preocupación latente puesto que el pueblo religioso se interrelaciona con el secularismo a partir de expresiones como las devociones que rayan con esperanzas mágicas, con prácticas marginales que excluyen la doctrina del magisterio de la iglesia, con prácticas afectivas alejadas de la racionalidad, con prácticas que solamente valoran el instante de la bendición a las imágenes o al agua. Así como los santos son vistos como milagrosos intercesores y protectores ante las adversidades de la vida, los sacramentos son asimilados como prácticas religiosas tradicionales de devoción y ritualización que muchas veces terminan en fiestas paganas y populares ${ }^{16}$.

13 Boff, Iglesia, carisma y poder, 42.

14 Zuluaga, La religiosidad popular colombiana, 36.

15 CELAM, Puebla, 83.

16 Galilea, Religiosidad populary pastoral hispanoamericana, 20. 


\section{Caracterización de los procesos de reconstrucción de la expresión religiosa.}

Hay realidades para las cuales el hombre no está preparado y no tiene las respuestas correspondientes como el dolor, el amor, la angustia, el más allá, la muerte, el sufrimiento entre otras. En otras palabras, son situaciones límite, que generan crisis existencial y para enfrentarlas, el hombre acude a la superstición, a la magia, a la mitología, a la religión, a los fenómenos paranormales o parareligiosos y tergiversa el verdadero sentido de lo trascendental, de lo mistérico, de lo religioso. "Las creencias populares, supersticiones y agüeros hacen parte de la mentalidad colectiva de nuestro pueblo latinoamericano"17.

Vivimos inmersos en un sinnúmero de expresiones, sentimientos, usos y actitudes que permean el entorno del hombre y que logran mitificar con valor religioso. Es el caso de la interpretación de los sueños, la lectura de los astros, las adivinaciones así como la lectura del tarot y el horóscopo. Esto ha generado un lenguaje contradictorio desde la comprensión de la lógica racional puesto que las experiencias manifiestas de la religiosidad dejan en manos de chamanes, teguas y demás los problemas de salud en lugar de asistir a un médico, o los eventos emocionales en manos de quienes no son psicólogos sino lectores del tarot o adivinos, es decir, que la institucionalidad es reemplazada por otros escenarios y ceremonias $^{18}$.

Sibien es cierto, no se puede negar que todos estos experienciarios ${ }^{19}$ responden a la influencia cultural de los pueblos indígenas aborígenes, a la mentalidad española incipiente, a los legados africanos, a las fuentes rurales, a las fuentes urbanas y las fuentes mestizas. Las comunidades siguen ritual izando la vida y la muerte con ceremonias acompañadas de cantos, oraciones y flores, con procesiones y letanías, con duelo, rezos y responsos. Muchos pueblos le temen a la muerte mientras que otros la celebran gozosos, conviven con ella en la ritualización.

Los pueblos integran en su cotidianidad eventos de buena suerte o mala suerte. Se puede encontrar en un hogar una mata de sábila, una herradura para la buena suerte y un crucifijo colgado en la pared, o una imagen de una virgen o el divino niño. Igualmente como se cree en la buena suerte, también se cree en la mala suerte. Llega final de año y aparecen los infinitos agüeros para la prosperidad en el siguiente año y al mismo tiempo se cuida de no derramar sal o evitar que se rompa un espejo o que pase al frente un gato negro. Para poder blindarse de estas fatalidades, muchas personas acuden a la compra de talismanes y amuletos, a contras, a la quiromancia, a la astrología, a la lectura del horóscopo y el tarot, al uso de piedras preciosas, a los rezos y los conjuros así como a la oración de los diferentes santos. Se visita un santuario, se participa en la Eucaristía y al mismo

17 Ocampo, Supersticiones y agüeros colombianos, 254.

18 Semán, La religiosidad popular: creencias y vida cotidiana, 26.

19 Experienciario: asumir la experiencia con sabiduría, con discernimiento. 
tiempo se pide agua bendita y un cuarzo de la buena suerte. Se genera una simbiosis entre la santería y el espiritismo, entre las tradiciones ancestrales, el sincretismo afro caribeño y las prácticas religiosas institucionalizadas ${ }^{20}$.

Es evidente que se abre un horizonte de multiformes expresiones religiosas con un arraigado sentido de pertenencia e influencia institucional sobre sus miembros y se queda a merced de los implícitos poderes subyacentes de la relación intrínseca entre la religión, la política y la economía. Entonces cabe hablar de aspectos como el mercadeo religioso configurado en la actividad proselitista que, según Prat, es agresiva en la búsqueda de nuevos adeptos y por consiguiente genera aversión y hostilidad frente a los demás grupos y expresiones religiosas ${ }^{21}$. Esto conlleva a que las personas se mantengan firmes en su adhesión de fe ya sea por convicción o por presión moral, física o psicológica. Este tipo de expresiones buscan nuevos escenarios para dar a conocer su propuesta religiosa y por lo tanto acuden a los medios de comunicación social y a las tecnologías de la información y la comunicación para llegar masivamente a sus interlocutores, para apoyarse en estrategias y herramientas como la programación neurolingüística.

Cada vez es más significativa y expresa la creatividad de ofertas espontáneas y estructuradas de lo religioso para adherir prosélitos a sus movimientos religiosos y esto se confirma en las diferentes advocaciones, fraternidades, invocaciones, prácticas y reconfiguraciones religiosas.

Para los obispos latinoamericanos reunidos en Puebla, deben existir algunos criterios y directrices para saber discernir la autenticidad de la fe en relación con prácticas y creencias de la religiosidad popular ${ }^{22}$. En este sentido, se evidencian aspectos positivos donde se afirma un humanismo esperanzado en realidades nuevas, en lo mistérico, en lo trascendente y en la praxis de la oración, de la meditación, de apertura hacia lo divino, de la solidaridad y la vivencia de principios religiosos. Pero al mismo tiempo se evidencia una clara mezcla de lo religioso con la superstición, con la magia, el ritualismo, el fetichismo, el esoterismo, el fatalismo fruto de la ignorancia, la desinformación, y el creciente avance del secularismo, de la influencia de sectas manipuladoras desde lo económico, lo político, lo psicológico y lo religioso.

Hay sectores conservadores que a la religiosidad popular la han visto con tolerancia y favorecimiento pero también hay sectores que la han condenado con actitud crítica denunciando sus desviaciones, sus connotaciones mágicosupersticiosas y alienantes reclamando desde las instancias institucionales la necesidad de discernimiento y purificación. Esta crítica devino en condena, abandono y desprecio al mismo tiempo que en posibilidad para ser tratada como

20 Velasco, Introducción a la fenomenología de la religión, 14.

21 Prat, El estigma del extraño: un ensayo antropológico sobre las sectas religiosas, 120.

22 CELAM, Puebla: La Evangelización en el presente y futuro de América Latina, 444- 449.

Signos, Lajeado, ano 39, n. 1, p. 316-331, 2018. ISSN 1983-0378 
genuina expresión de los pueblos como un fenómeno socio-pastoral motivo de estudio e interpretación ${ }^{23}$.

La religiosidad popular se presenta matizada por sincretismo y prácticas funcionales. En cuanto al primero, caracterizador de esta expresión religiosa, ha dado lugar a la mezcla de sinnúmero de elementos y factores religiosos, animistas, de concepciones ancestrales, de rituales curativos y sanadores propios de las tradiciones populares. Paralelamente se presentan una serie de prácticas que se asumen como mandatos para cumplir de manera puntual y que al no hacerlo podría devenir en fracasos. Tal es el caso de cumplir con visitas a santuarios para obtener indulgencias y esto patrocinado por quienes lideran las iglesias desde la jerarquía eclesiástica. En la expresión de lo religioso popular se evidencian principios doctrinales del cristianismo amañado con eventos mágicos y místicos ${ }^{24}$.

Con todo lo anterior, se pueden presentar algunas características de los procesos de reconstrucción de la expresión religiosa las cuales se evidencian a partir de las motivaciones tradicionales transmitidas de generación en generación. Como base fundamental está el sentido de crear conciencia comunitaria de unidad familiar, regional, barrial, rural en torno a celebraciones, ceremonias y ritos religiosos apoyándose en la fuente escrita del texto sagrado con su lectura e interpretación para así darle más sentido a su experiencia de fe y su vida cotidiana ligada a la práctica religiosa.

Estas características son manifiestas por ejemplo en la conformación de fraternidades, en la participación de procesiones, de visitas a santuarios en las festividades y demás eventos de práctica religiosa. En este sentido también se encuentra el valor que se le brinda a lo simbólico, a lo semiótico, a los signos y los íconos representativos. Cabe destacar el papel de los santos oficiales y no oficiales no como ejemplo de virtudes, sino como intercesores poderosos y milagrosos. Igualmente están las imágenes de la Virgen en todas sus advocaciones y el Cristo que pende como pectoral, tanto de jerarcas como de fieles laicos o la cruz que cuelga en las paredes de los templos, las paredes de las casas o plantado en lo más alto de una montaña.

Otro elemento caracterizador y de tradición popular es la necesidad de recibir la bendición o signarse con agua bendita así como recibir la bendición para una propiedad como una casa o un auto o al salir de viaje; se acostumbra presentar a los niños ante la Virgen y ser bendecidos por un ministro ordenado.

Otra característica afianzadora de la expresión religiosa está en el culto que se le brinda a la muerte y por consiguiente a los difuntos. Los velorios, las visitas a los cementerios, los responsos, las misas, los novenarios, las coronas, la música e incluso los festines en honor del difunto.

23 Scannone, Enfoques teológico pastorales latinoamericanos de la religiosidad popular, 261-274.

24 Parker, Religión y clases subalternas, 289.

Signos, Lajeado, ano 39, n. 1, p. 316-331, 2018. ISSN 1983-0378 


\section{Conclusión.}

Desde el referente cultural, la religiosidad popular es portadora de valores esenciales del pueblo latinoamericano así como de su ethos cultural lo cual la convierte en dinamismo de transformación social pero también de instrumentalización y manipulación ideológica. En este sentido, para Gutiérrez, la religiosidad popular se convierte en un escenario de emancipación, de liberación y de expresión propia de la espiritualidad de los pobres ${ }^{25}$.

Los pueblos latinoamericanos viven una adveniente e irreversible reconfiguración de lo religioso manifestado en la revitalización religiosa que va más allá de las estructuras organizacionales e institucionales eclesiásticas. Así mismo hay una creciente demanda expresando que sus esperanzas religiosas no llenan sus expectativas. Por otra parte, es innegable que hay desconocimiento y por lo tanto desorientación religiosa en individuos y colectivos sociales y mucho más en grupos poblacionales de poca formación académica. Por último, es claro que se presenten miradas fundamentalistas en las expresiones religiosas a tal punto que muchos individuos chocan literalmente con otros, porque no pertenecen a su grupo religioso, porque no confiesan su experiencia de fe y caen en la intolerancia de la fe, en el proselitismo y el fanatismo desmedido y despiadado.

América Latina es un pueblo que manifiesta su fe incipiente en la piedad popular. Desde el contexto de la sociología la religiosidad popular tiene que ver con la manifestación de las masas en donde la mayoría de los individuos son pasivos y simples espectadores con poca profundidad en los procesos participativos y de compromiso social. En este sentido, las creencias religiosas son practicadas como mezclas que involucran el patrimonio ancestral indígena. La intermediación de los santos es vital para establecer contacto con Dios al brindar confianza y ser más cercanos a la realidad cotidiana de las personas porque los pueden visualizar en sus representaciones escultóricas e imágenes.

La religiosidad popular se circunscribe en medio de los problemas que vive el hombre latinoamericano, en medio de sus angustias, de sus esperanzas, de su sentir liberador y anhelante de justicia social, en medio de las burocracias de turno, de las situaciones de opresión, de los problemas macro y micro de los pueblos, de sus conflictos y sus situaciones límite personales, familiares y laborales. Frente a estas situaciones límite, el hombre busca protección en la religión que puede ser alienante o liberadora.

En medio de todas estas circunstancias, la piedad popular es una clara expresión de la necesidad y sed de Dios que los pobres llevan en su corazón ${ }^{26}$. Estas expresiones mueven los corazones de los pobres y sencillos ${ }^{27}$ las cuales para

25 Gutiérrez, Teología de la liberación, 45.

26 Evangelii Nuntiandi, 48.

27 Catechesi Tradendae, 54. 
quienes no las vivencian pueden pasar por ser ridículas manifestaciones de afecto religioso ${ }^{28}$.

La piedad popular se ha mantenido presente y con resistencia a desaparecer cambiando en lo formal pero no en lo fundamental. Lo institucional litúrgico ha tenido que amoldarse y armonizar con estas expresiones populares matizadas por la ignorancia frente a la vivencia inadecuada de la religión oficial ${ }^{29}$. Estos movimientos populares han puesto en evidencia que la liturgia oficial ha tenido que dialogar con ellos para establecer su validez y presencialidad activa en las celebraciones institucionales y también ha tenido que despojarse de su acostumbrado sentido de superioridad eclesiástica que ha mirado lo popular como no sistemático y de poca valía tradicional.

La distinción que se ha presentado entre la religión oficial y la piedad popular obedece a la manera como se ha ejercido el control social sobre una y otra ${ }^{30}$. La distinción corresponde al poder que se establece frente al control sobre las expresiones religiosas mas no en las concepciones cósmicas, vitales y populares en contraposición con lo revelado, lo histórico e institucional de la ortodoxia y práxis oficiales.

Para Estrada ${ }^{31}$, la religiosidad popular pertenece a los pueblos incultos $\mathrm{y}$ rústicos quienes han vivenciado y comprendido inadecuadamente estas expresiones religiosas como una mezcla fruto de la verdad revelada de carácter oficial y la expresión de su ignorancia religiosa. En este sentido, han dado lugar a manifestaciones cósmicas ${ }^{32}$ que mantienen múltiples variables a la hora de evidenciar su adhesión de fe. Según Messlin ${ }^{33}$, la religiosidad popular es una búsqueda de Dios desde una perspectiva más sencilla, menos abstracta, esquemática y sistematizada. Estas expresiones no surgen por convicción y conversión frente a los principios dogmáticos y las enseñanzas doctrinales del magisterio eclesiástico, sino que surgen obedeciendo a comportamientos que han sido patrimonio de la tradición y herencia de los pueblos.

La religiosidad popular permite interactuar con la cultura, con los contextos sociales de los pueblos, su arraigamiento particular y sentido con su entorno regional de vida sencilla. La piedad popular acompaña la religión oficial haciendo que su lenguaje doctrinal y magisterial sea entendido por los más humildes y sencillos en su quehacer cotidiano. Desde la religiosidad popular se vivencia la experiencia de

28 Newman, Lettera al rev. Pusey su Maria e la vita cristiana, 155.

29 Maldonado, Para comprender el catolicismo popular, 17.

30 García, El contexto de la religiosidad popular, 19.

31 Estrada, La transformación de la religiosidad popular, 19.

32 Maldonado, Introd. a la religiosidad popular, 44.

33 Messlin, Le phénomène religieux populaire, 2-16.

Signos, Lajeado, ano 39, n. 1, p. 316-331, 2018. ISSN 1983-0378 
fe de quienes buscan a Dios, de quienes quieren encontrar refugio en su presencia aun cuando no tengan la suficiente madurez doctrinal y teológica para responder con convicción a los principios orientadores del magisterio de la Iglesia. Son los hombres y mujeres de a pie que de manera sencilla se acercan a Dios y le rinden tributo con diversas creencias y rituales para obtener sus favores al clamor de sus plegarias y oraciones. La religiosidad popular está inscrita en el contexto del sentido común y sus expresiones sencillas ${ }^{34}$ así como responde a las experiencias personales, culturales y sociales de quienes las vivencian y expresan dramáticamente en su devenir histórico ${ }^{35}$.

Es necesario, por lo tanto, articular la praxis con la teoría y establecer un diálogo crítico que supere los antagonismos entre las creencias y las prácticas de religiosidad popular de tal manera que se asuma respetuosa, consciente, libre y con madurez las prácticas religiosas a fin de no tergiversar el sentido auténtico de las mismas.

El pueblo celebra su vida y expresa en la oración y con lenguajes simbólicos y emocionales el profundo amor y veneración a la imagen del Señor, a su santo o a una advocación mariana de manera creativa, sencilla y auténtica a partir de la Piedad Popular que es una legítima forma de espiritualidad y un agente evangelizador que ayuda a vitalizar a la Iglesia misma la cual no debe ver estas manifestaciones religiosas populares como experiencias para racionalizar intelectualmente sino para asumirlas como experiencias de vida y de fe.

\section{Referencias}

Boff, L. Iglesia, carisma y poder, ensayos de eclesiología militante. Santander: Sal Terrae, 1985.

Boff, Leonardo. Igreja, carisma e poder. Rio de Janeiro: Editorial Record, 2005.

Catechesi tradendae (CT, 54).

CELAM. La Evangelización en el presente y futuro de América Latina: Tercera Conferencia. Puebla: CELAM, 1979.

Delgado, M. (1993): La religiosidad popular: en torno a un falso problema. En: Gazeta de antropología. 1993, 10-20.

Eliade, M. Aspectos del mito. Barcelona: Paidós - Ibérica, 2000.

Estrada, J. A. La transformación de la Religiosidad Popular, Sígueme, Salamanca, 1986.

Evangelii Nuntiandi, 48.

34 Lonergan, Método en teología, 47.

35 Neira, Un ejercicio de dialéctica, 60. 
Galilea, S. Religiosidad popular y pastoral hispanoamericana. New York: Centro Católico de Pastoral para Hispanos del Nordeste, Inc., 1981.

García, J. L. "El contexto de la Religiosidad Popular", en Álvarez, C (et al.) (eds.); La religiosidad popular, Editorial Anthropos, Barcelona (Antropología e Historia) 1989: 19.

Gil, J. \& Nistal, J. New age: una religiosidad desconcertante. Barcelona: Herder, 1994

Gutiérrez, G. Teología de la liberación, perspectivas. Salamanca: Sígueme, 1972.

Houtart, F. Sociología de la religión. Managua: Nicarao, 1992.

III Conferencia General del Episcopado Latinoamericano: La evangelización en el presente y en el futuro de América Latina, Puebla, 1979. P. 83.

Lonergan, B. Método en teología, Citado por Zuluaga, Francisco. Religiosidad popular campesina. Bogotá: Centro Editorial Javeriano. 1995.

Maldonado, L. Introducción a la religiosidad popular. Santander: Editorial Sal Terrae, 1985. Para comprender el catolicismo popular. Santander: Verbo Divino, Estella, 1990.

Messlin, M. "Le phénomène religieux populaire", en Lacroix, B. y Boglioni, P. (eds.), Les religions populaires, Les Presses de l'Université Laval, Quebec 1972, 2-16.

Neira, G. Un ejercicio de dialéctica: interpretaciones de la religiosidad popular en América Latina (1960 - 1980). Bogotá: Pontificia Universidad Javeriana, 2005.

Newman, J. H. Lettera al rev. Pusey su Maria e la vita cristiana (1865). Roma: Città Nuova, 1975.

Ocampo, J. Supersticiones y agüeros colombianos. Bogotá: El Áncora Editores, 1985.

Parker, C. Religión y clases subalternas urbanas en una sociedad dependiente. Religiosidad popular urbana en América Latina. Un estudio de caso en Chile. Bélgica: Université Catholique de Louvain, 1986.

Prat, J. El estigma del extraño: un ensayo antropológico sobre las sectas religiosas. Barcelona: Ariel. 1997.

Richard, P e Irrazabal, D. Religión y politica en América Latina. Hacia una interpretación de la religiosidad popular. San José de Costa Rica: Departamento Ecuménico de Investigaciones (DEI), 1987.

Scannone, J. C. Enfoques teológico pastorales latinoamericanos de la religiosidad popular. En: Stromata 3- 4: 1984, 261-274.

Semán, P. La religiosidad popular: creencias y vida cotidiana. Buenos Aires: Capital Intelectual, 2004.

Velasco, J. M. Introducción a la fenomenología de la religión. Madrid: Cristiandad, 1980.

Zuluaga, F. La religiosidad popular colombiana. Bogotá: Pontificia Universidad Javeriana.

Colección profesores, n.7: 1997. 